\title{
Synergy of chemists and biologists
}

THF introduction of genetic engineering techniques has turned pharmaceutical research on its head, and Ciba-Geigy's Jakob Nüesch has seen the effects at first hand. At first, there was antagonism between chemists - traditionally the top dogs in drug development - and molecular biologists, whose work came as "a shock", says Nüesch, to a rigidly organized industry.

At first, says Nüesch, director of CibaGeigy's pharmaceutical research division, pharmacologists reacted with a disbelieving "Oh, come on!" when told that custom peptide biosynthesis could now be done in seconds by genetically modified microorganisms. They wagered that human insulin, for example, would never be made by these methods.

The success of 'genetic engineering' is no longer in doubt, and the "tension" has given way, says Nüesch, to "an excellent integration" between chemists and biologists that is "a joy to watch". Chemists have found a "new self-confidence" after the crisis and both sides have recognized the need for cooperation.

"The chemists have to become more biological", says Nüesch, "just as the biol-

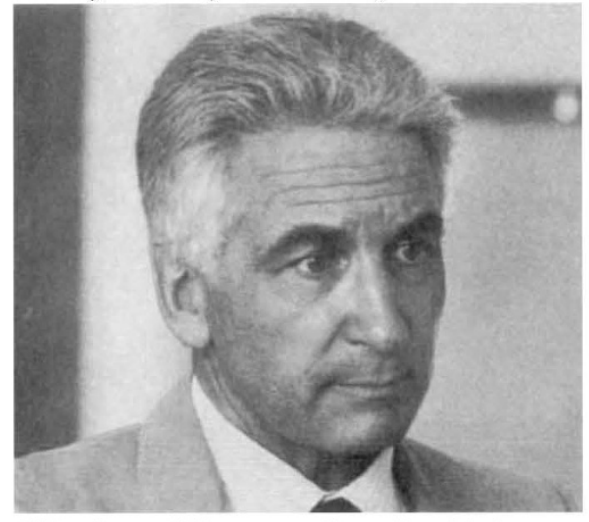

Nüesch: presiding over a time of rapid change. ogists have become more chemical". Through it all, Ciba-Geigy has maintained its position as one of the top three producers worldwide of dyestuffs, pharmaceuticals and agricultural chemicals. Nearly 3,000 of the 11,000 employees in Basle are involved in research and development. The company was formed in 1970 by the merger of CIBA, where epoxy resins were first developed, and Geigy, whose chemist Paul Müller had discovered the insecticidal properties of DDT, for which he received the 1948 Nobel prize for Physiology or Medicine. Overall, there are 24,000 employees in Switzerland and 82,000 in the world.

Although half the university graduates hired by Ciba-Geigy are chemists, there are more postdoctoral fellows (whose work is nearer the cutting edge of basic research) in the biological sciences than in

chemistry. This has to do with the different "maturities" of the two fields. But despite the increasing investment in biotechnology, controversial treatments like somatic gene therapies are "a really longterm thing", says Nüesch. There has been unwarranted optimism in this area, unjustified because "so few diseases are the result of a single gene". Nüesch rejects the idea of experimenting on the human germ-line, saying "even if we saw a possibility to develop therapies in this direction, we wouldn't do it".

By contrast, a major growth area in pharmaceutical development is neuromolecular biology. This comes as no surprise at Ciba-Geigy, which has traditionally been a major producer of psychoactive drugs such as tranquillizers and compounds against epilepsy.

S.D.

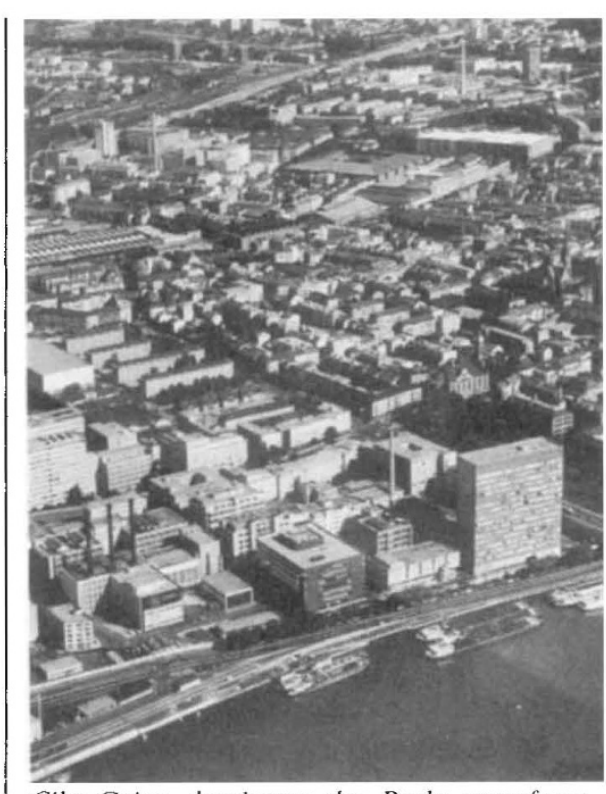

Ciba-Geigy dominates the Basle waterfront, employing 11,000 people in the city.

\section{Hoffmann-La Roche}

\section{Biotechnology now to the fore}

INTERNATIONAL pharmaceutical giant F. Hoffmann-La Roche \& Co. (Roche for short) invests a fifth of its pharmaceutical division budget in research, more than its Basle brethren Ciba-Geigy and Sandoz. The company is moving rapidly into biotechnology and genetic engineering despite growing public disquiet about the consequences (see page 330 ).

With more than 6,500 employees at its corporate headquarters and research and development and production facilities in Basle (out of 46,000 worldwide), Roche must be concerned about the views of the citizens. A series of public forums has been held on subjects such as the sideeffects of the acne medicine Accutane, and the effects of degenerative neurological diseases. The forums feature top Roche executives, says spokesman Eckart Gwinner, and are meant to "show how we can unify our commercial goals with the health of the population".

Roche made its name as the first largescale producer of vitamin $\mathrm{C}$ in the $1930 \mathrm{~s}$ and vitamin $\mathrm{A}$ in the $1940 \mathrm{~s}$. 'Vitamins and fine chemicals' still account for more than a quarter of the total sales. The company also derived big profits from sulphonamide antibiotics beginning in 1949 and from the benzodiazepene tranquillizers that are the active ingredients in Librium (introduced in 1960) and Valium (1963).

An investment in biotechnology began to pay dividends in 1986 with the introduction of interferon alpha- $2 \mathrm{a}$, licensed under the name Roferon- $A$. The compound has been licensed in several countries as a treatment of hairy-cell leukaemia, Kaposi's sarcoma and other cancers.

But modern molecular biology at
Roche did not really take off until Hermann Bujard was hired to lead the biology department. Bujard, currently director of the Centre for Molecular Biology in Heidelberg, West Germany, assembled an excellent research staff in the early 1980 s. Publication began to be encouraged, and interaction with the Basle Institute for Immunology (BII) was promoted.

The present head of biology research Michael Steinmetz, himself from BII, explains where Roche is headed: "The

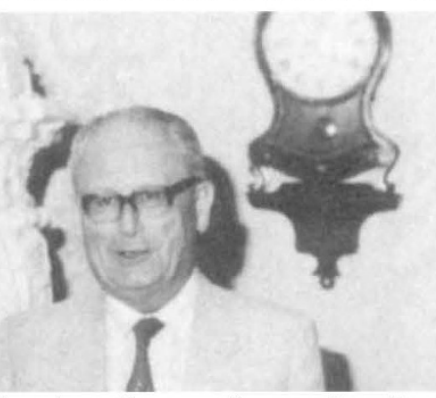

Alfred Pletscher, director of research at Roche in the 1960s when the Basle Biozentrum was established (page 334). Now president of the Swiss Academy of Medical Sciences.

trend now is to find novel chemical compounds that replace or inhibit factors that play a role in immune response, such as interleukins and interferons." For example, Roche researchers are looking for a non-peptide interferon-gamma antagonist in microorganisms.

Other projects under way in the biology department include the search for a malaria vaccine (which even if found will probably not recover the investment made) and development of AIDS therapeutics and diagnostics. 